\title{
Effect of Filgrastim in a Severe Leucopenia associated Parvoviral Enteritis in Rottweiler
}

\author{
M. Areshkumar ${ }^{1 *}$, P. Vijayalakshmi ${ }^{1}$, S. Venkatesa Perumal ${ }^{2}$ and D. Selvi ${ }^{1}$ \\ ${ }^{1}$ Department of Veterinary Medicine, Rajiv Gandhi Institute of Veterinary Education and \\ Research, Teaching Veterinary Clinical Campus, Mettupalayam, Puducherry, India \\ ${ }^{2}$ Department of Veterinary Biochemistry, Rajiv Gandhi Institute of Veterinary Education and \\ Research, Teaching Veterinary Clinical Campus, Mettupalayam, Puducherry, India \\ *Corresponding author
}

\begin{tabular}{|c|c|}
\hline & A B S T R A C T \\
\hline & $\begin{array}{l}\text { Filgrastim (Colstim } ®) \text { is a recombinant Methionyl Human Granulocyte Colony- } \\
\text { Stimulating Factor (r-metHuG-CSF) analog used to stimulate the proliferation and }\end{array}$ \\
\hline Keywords & $\begin{array}{l}\text { differentiation of granulocytes in humans undergoing chemotherapy with granulocyte } \\
\text { values below } 0.5 \mathrm{G} / \mathrm{l} \text { likely to be threatened by infections, including sepsis possibly with a }\end{array}$ \\
\hline Filgr & fatal outcome. A four month old female Rottweiler pup was presented to the TVCC, \\
\hline $\begin{array}{l}\text { Leucopenia, } \\
\text { Granulocyte colony } \\
\text { stimulating factor. }\end{array}$ & $\begin{array}{l}\text { RIVER with the history of vomiting and melena for the past two days. Further enquiry } \\
\text { revealed that the pup had properly been immunized against all infectious diseases. Clinical } \\
\text { examination showed a pink and moist conjunctival mucosa, rectal temperature of } 38.7^{\circ} \mathrm{C} \text {, }\end{array}$ \\
\hline Article Info & $\begin{array}{l}\text { hear rate } 150 \mathrm{bpm} \text {, and capillary refill time of } 3 \text { seconds. The ECG showed a normal study. } \\
\text { Laboratory examination revealed } \mathrm{Hb}-15.6 \mathrm{~g} \% \text {, PCV }-45.5 \% \text {, RBC count }-5.87\end{array}$ \\
\hline $\begin{array}{l}\text { Accepted: } \\
12 \text { March } 2017 \\
\text { Available Online: } \\
10 \text { April } 2017\end{array}$ & $\begin{array}{l}\text { millions } / \mathrm{mm}^{3} \text {, WBC count }-1000 \text { cells } / \mathrm{mm}^{3} \text {, platelets }-4.21 \text { lakhs } / \mathrm{mm}^{3}, \mathrm{MCV}-77.6 \mathrm{fl} \text {, } \\
\mathrm{MCH}-26.5 \mathrm{pg}, \mathrm{MCHC}-34.2 \% \text {. Absolute count of Neutrophils }-500 \text { cells } / \mathrm{mm}^{3} \text {, } \\
\text { Lymphocytes }-450 \text { cells } / \mathrm{mm}^{3} \text {, Monocytes }-40 \text { cells } / \mathrm{mm}^{3} \text { and Eosinophils }-10 \text { cells/ } \\
\mathrm{mm}^{3} \text {. However, serum biochemistry showed normal values but with an increase in }\end{array}$ \\
\hline & $\begin{array}{l}\text { Creatine kinase of } 567 \mathrm{U} / \mathrm{L} \text {. The dog was treated with Filgrastim @ } 10 \mu \mathrm{g} / \mathrm{kg} \mathrm{b} \text {.wt. S.c } \\
\text { along with other supportives. After } 5 \text { days of therapy the dog recovered uneventfully. }\end{array}$ \\
\hline
\end{tabular}

\section{Introduction}

Canine Parvovirus (CPV) emerged as a new pandemic disease in dogs with first report from United States in 1978. In subsequent years it was widely reported from Canada, Australia, England, Asia and European countries. In India, the disease was first reported in Madras in 1981 by Balu and Thangaraj. Parvovirus infection in dogs, especially in the young ones, may result in a severe and fatal disease (Greene, 1984). Glickman et al., (1985), Greene and Decaro (2012) claimed that Doberman Pincher,
Rottweiler, Labrador retriever, German shepherd, Alaskan sled dog, American Staffordshire terriers and English springer spaniels were significantly susceptible to CPV enteritis. CPV spreads rapidly from dog to dog via oronasal exposure to contaminated faeces. CPV localizes predominantly in the gastrointestinal epithelium lining the tongue, oral and esophageal mucosae and small intestine and lymphoid tissue, such as thymus, lymph nodes and bone marrow. It can also be isolated from the lungs spleen, liver, kidney 
and myocardium (Greene, 1984). CPV also destroys mitotically active precursors of circulating leukocytes and lymphoid cells. In severe infections, the results are often neutropenia and lymphopaenia.

Filgrastim (Colstim $\left.^{\circledR}\right)$ is a recombinant Methionyl Human Granulocyte ColonyStimulating Factor (r-metHuG-CSF) analog used to stimulate the proliferation and differentiation of granulocytes in humans undergoing chemotherapy with granulocyte values below $0.5 \mathrm{G} / 1$ likely to be threatened by infections, including sepsis possibly with a fatal outcome (Novotny et al., 1995). Filgrastim is a non-glycosylated, 175 amino acid containing protein, which is produced recombinantly by $E$. coli. Filgrastim has a molecular weight of $18.8 \mathrm{kDa}$. It regulates the production and release of functional neutrophils from bone marrow within 24 hours of administration. Filgrastim results in increase in peripheral blood neutrophil counts with minor increases in monocytes.

\section{Materials and Methods}

A four month old female Rottweiler pup was presented to the TVCC, RIVER with the history of vomiting and melena for the past two days. Further enquiry revealed that the pup had properly been immunized against all infectious diseases.

\section{Clinical Assessment}

Clinical examination showed a pink and moist conjunctival mucosa, rectal temperature of $38.7^{\circ} \mathrm{C}$, heart rate $150 \mathrm{bpm}$, and capillary refill time of 3 seconds (Fig. 1). The ECG showed a normal study (Fig. 2) (Table 1).

\section{Laboratory Assessment}

The following table 2 shows the hematological values of CPV affected pup on
Day I, II and III respectively and table 3 shows the serum biochemical values.

\section{Diagnosis}

The faecal sample was collected for the CPV diagnosis by Polymerase Chain Reaction (PCR) and it was positive (Fig. 3) by using primer pair $\mathrm{H}_{\text {for }} / \mathrm{H}_{\text {rev }}$ that amplify a large fragment of the capsid protein-encoding gene (VP2) of CPV-2 (Buonavoglia et al., 2001). Primer $\mathrm{H}_{\text {for }}\left(5^{\prime}\right.$ CAG GTG ATG AAT TTG CTA CA3') and $\mathrm{H}_{\text {rev }}$ (5' CAT TTG GAT AAA CTG GTG GT 3'), located at nucleotide position 3556-3575 and 4166-4185 of the CPV genome respectively yield 630bp product.

\section{Sequence Analysis}

For the sequencing PCR products were purified and sequenced from Eurofins Genomics India Pvt. Ltd., Bengaluru, Karnataka. It was analyzed and compared with the available CPV sequences in the gene bank using NCBI BLAST http://blast.ncbi.nlm.nih.gov/blast.cgi

(Altschul et al., 1997). It had 100\% identity with the corresponding Canine parvovirus 2a isolate OB4 VP2 capsid protein gene, partial sequence (Gene bank accession number JX683402.1)

\section{Clinical Management and Outcome}

The dog was treated with Inj. Filgrastim @ 10 $\mu \mathrm{g} / \mathrm{kg}$ b.wt. subcutaneously (Morris and Dobson, 2001) along with supportive therapy includes table 4.

\section{Results and Discussion}

In CPV infected pups death can occur at any age, depending on when maternally derived antibody (MDA) wanes. 
Table.1 Clinical assessment

\begin{tabular}{|c|c|c|c|c|c|c|c|c|}
\hline \multicolumn{2}{|c|}{ (Table 1) P wave } & \multicolumn{2}{|c|}{ QRS complex } & \multirow{2}{*}{$\begin{array}{c}\text { PR } \\
\text { interval } \\
(\mathrm{sec})\end{array}$} & \multirow{2}{*}{$\begin{array}{c}\text { ST } \\
\text { segment }\end{array}$} & \multirow{2}{*}{$\begin{array}{c}\text { QT } \\
\text { interval } \\
(\mathrm{sec})\end{array}$} & \multirow{2}{*}{$\begin{array}{c}\text { T wave } \\
\text { Amplitude } \\
(\mathrm{mV})\end{array}$} & \multirow{2}{*}{$\begin{array}{c}\text { T wave } \\
\text { Amplitude }\end{array}$} \\
\hline$\underset{(\mathrm{mV})}{\text { Amplitude }}$ & $\begin{array}{c}\text { Duration } \\
(\mathrm{sec})\end{array}$ & $\begin{array}{c}\text { Amplitude } \\
(\mathrm{mV})\end{array}$ & $\begin{array}{c}\text { Duration } \\
\text { (sec) }\end{array}$ & & & & & \\
\hline 0.15 & 0.04 & 1.2 & 0.04 & 0.08 & Elevated & 0.12 & 0.2 & Positive \\
\hline
\end{tabular}

Table.2 Hematological values of CPV

\begin{tabular}{|c|c|c|c|c|}
\hline PARAMETER & Day I & Day II* & Day III** & Normal value \\
\hline Hemoglobin $(\mathrm{g} / \mathrm{dL})$ & 15.6 & 13.2 & 11 & $12-18$ \\
\hline PCV (\%) & 45.5 & 40.1 & 32.3 & $37-55$ \\
\hline RBC (million $/ \mathrm{mm}^{3}$ ) & 5.87 & 4.9 & 4.43 & $5.5-8.5$ \\
\hline WBC (cells $/ \mu \mathrm{L}$ ) & 1000 & 5800 & 7800 & $6000-17000$ \\
\hline Platelets (lakhs $/ \mu \mathrm{l})$ & 4.21 & 4.20 & 4.42 & $2.0-5.0$ \\
\hline Neutrophils (cells/ $\mathrm{mm}^{3}$ ) & 500 & 4118 & 7332 & $3000-11,500$ \\
\hline Lymphocytes (cells/ $\mathrm{mm}^{3}$ ) & 450 & 1624 & 312 & $1000-4800$ \\
\hline Monocytes (cells/ $\mathrm{mm}^{3}$ ) & 40 & 58 & 78 & $150-1350$ \\
\hline Eosinophils(cells/ $\left.\mathrm{mm}^{3}\right)$ & 10 & - & 78 & $100-1250$ \\
\hline MCV (fL) & 77.6 & 81.8 & 73.1 & $60-77$ \\
\hline $\mathrm{MCH}(\mathrm{pg})$ & 26.5 & 26.9 & 24.8 & $21-32$ \\
\hline $\mathrm{MCHC}(\%)$ & 34.2 & 32.9 & 34.0 & $32-36$ \\
\hline
\end{tabular}

Table.3 Serum biochemical values

\begin{tabular}{|l|l|l|}
\hline Parameter & Observed Values & Normal Value \\
\hline BUN $(\mathrm{mg} / \mathrm{dl})$ & 12 & $12-25$ \\
\hline Creatinine $(\mathrm{mg} / \mathrm{dl})$ & 0.6 & $0.5-1.5$ \\
\hline Protein Total $(\mathrm{g} / \mathrm{dl})$ & 5.3 & $5.2-8.2$ \\
\hline Albumin $(\mathrm{g} / \mathrm{dl})$ & 2.6 & $2.3-4.0$ \\
\hline Globulin $(\mathrm{g} / \mathrm{dl})$ & 2.7 & $2.5-4.5$ \\
\hline Potassium $(\mathrm{Mmol} / \mathrm{L})$ & 4.6 & $3.8-5.8$ \\
\hline Glucose $(\mathrm{mg} / \mathrm{dL})$ & 105 & $74-143$ \\
\hline ALP U/L & 81 & $23-212$ \\
\hline CK U/L & 567 & $10-200$ \\
\hline
\end{tabular}


Table.4 Supportive therapy

\begin{tabular}{|l|c|c|}
\hline \multicolumn{1}{|c|}{ Drug } & Dose (per Kg B.wt) & Dosage \\
\hline Inj. Lactate ringer solution & $10 \mathrm{ml}$ & BID \\
\hline Inj. Dextrose 5\% & $10 \mathrm{ml}$ & BID \\
\hline Inj. Metronidazole & $25 \mathrm{mg}$ & BID \\
\hline Inj. Astymin-3 & $1 \mathrm{ml}$ & BID \\
\hline Inj. Intralipid $^{\circledR}$ & $1 \mathrm{ml}$ & BID \\
\hline Inj. Ondansetron & $0.1 \mathrm{mg}$ & BID \\
\hline Inj. Ranitidine & $2 \mathrm{mg}$ & BID \\
\hline Inj. Cefotaxime & $40 \mathrm{mg}$ & BID \\
\cline { 2 - 3 }
\end{tabular}

After 5 days of therapy the dog recovered uneventfully.

Fig.1 Shows the affected animal

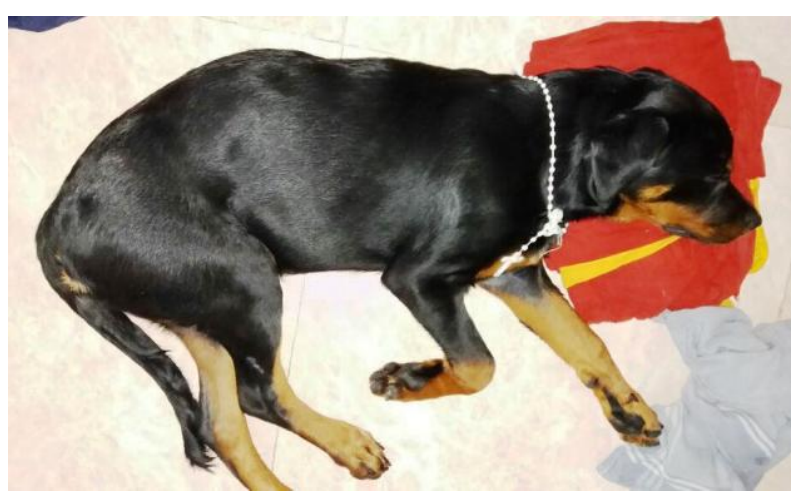

Fig.2 Electrocardiogram of Parvovirus infected dog

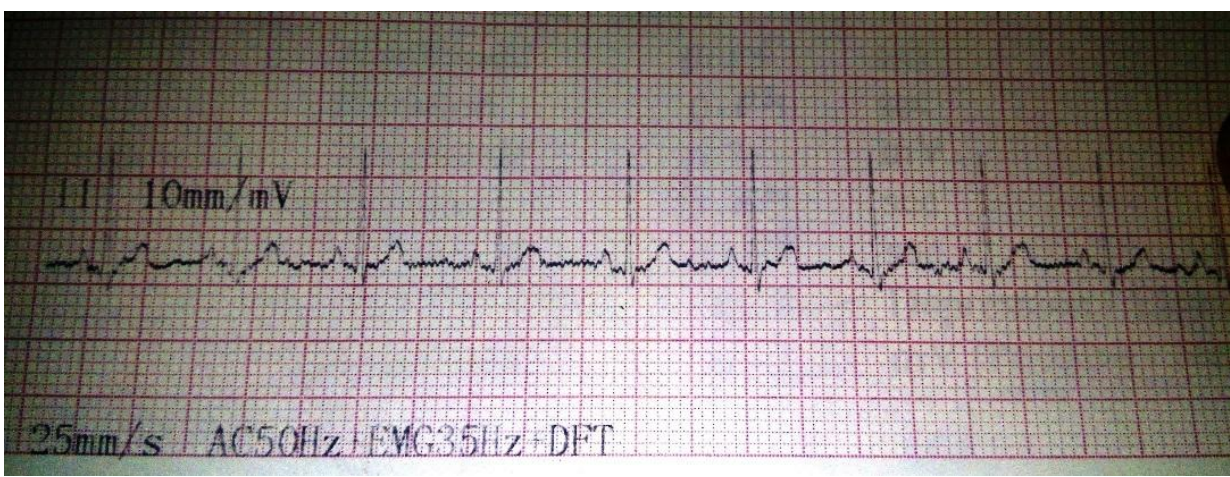


Fig.3 1. Negative control, 2. Sample, 3. Positive control (vaccine), 4. DNA marker (100bp)

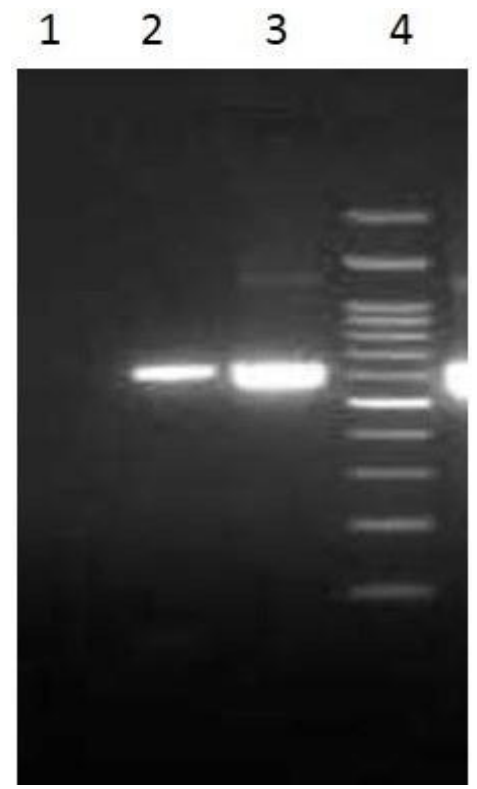

It causes acute hemorrhagic gastroenteritis in dogs and is prone to genetic evolution mainly due to the mutations in VP2 gene (Mohan et al., 2010). In this case, although the dog vaccinated properly, occurrence of the disease noticed and the leukocytes count (1000 cells $/ \mu \mathrm{L})$ was very low. To overcome this Inj. Filgrastim at the dose rate of $10 \mu \mathrm{g} / \mathrm{kg}$ body weight (dose rate $5-15 \mu \mathrm{g} / \mathrm{kg}$ ) was administered. After 24 hours of the injection the leucocyte count was elevated to 5800 cells $/ \mu \mathrm{L}$. Greene and Decaro (2012) reported that those pups dying from the disease generally have TLC equal to or less than 1030 cells/ $\mu 1$ and have persistent lymphocytopenia, monocytopenia and eosinopenia within the first 3 days of hospitalization. Even though Rottweiler is a predisposing breed to CPV (Glickman et al., 1985), the administration of Filgrastim will improve the survival rate if it is administered at the early stage of the disease along with other supportive therapy.

\section{References}

Altschul, S.F., Madden, T.L., Schaffer, A.A., Zhang, J., Zhang, Z., Miller, W. and Lipman, D.J. 1997. Gapped BLAST and
PSI-BLAST: a new generation of protein data-base search programs. Nucleic Acids Res., 25: 3389-3402.

Balu, P.A. and T.M. Thangaraj. 1981. Canine viral gastroenteritis - A clinical report. Indian J. Vet Med., 1: 73.

Buonavoglia, C., Martella, V., Pratelli, A., Tempesta, M., Cavalli, A. and Buonavoglia, D. 2001. Evidence for evolution of canine parvovirus type- 2 in Italy. J. Gen. Virol., 82: 3021-3025.

Glickman, L.T., L.M. Domanski., G.J. Patronek and F. Vistainer. 1985. Breed related risk factors for canine parvovirus enteritis. J. Am. Vet. Med. Assoc., 187: 589-594.

Greene, C.E. 1984. Canine viral enteritis. Infectious diseases of the dog and cat. Philadelphia, W.B. Saunders, pp. 22037.

Greene, C.E. and Decaro, N. 2012. Canine viral enteritis. In: Greene CE, editor. Infectious diseases of the dog and cat $4^{\text {th }}$ ed. St. Louis: Elsevier; pp. 67-80.

Mohan Raj, J., Mukhopadhyay, H.K., Thanislass, J., Antony, P.X. and Pillai R.M. 2010. Isolation, molecular 
characterization and phylogenetic analysis of Canine parvovirus. Infect. Genet. Evol., 10(8): 1237-1241.

Morris, J. and Dobson. J. 2001. Small animal oncology, Black well sci. 1td. Pp 288
Novotny, J., M. Zvarova, L. Prazakova, M. Jandlova and L. Konvickova. 1995. GCSF in the treatment of patients with chronic aplastic anemia with severe neutropenia, Vnitr Lek., 41(10): 692-5.

\section{How to cite this article:}

Areshkumar, M., P. Vijayalakshmi, S. Venkatesa Perumal and Selvi, D. 2017. Effect of Filgrastim in a Severe Leucopenia associated Parvoviral Enteritis in Rottweiler. Int.J.Curr.Microbiol.App.Sci. 6(4): 1060-1065. doi: https://doi.org/10.20546/ijcmas.2017.604.131 